\title{
RETRACTED ARTICLE: Net Fluorescein Flux Across Corneal Endothelium Suggests Fluid Transport is Driven by Electroosmosis
}

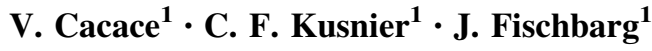

Received: 25 June 2015/Accepted: 18 September 2015/Published online: 30 September 2015

(C) The Author(s) 2015. This article is published with open access at Springerlink.com

This article has been retracted at the request of the Corresponding Author. The retraction has been agreed due to flaws in the data. The authors regret the oversight.

Open Access This article is distributed under the terms of the Creative Commons Attribution 4.0 International License (http://crea tivecommons.org/licenses/by/4.0/), which permits unrestricted use, distribution, and reproduction in any medium, provided you give appropriate credit to the original author(s) and the source, provide a link to the Creative Commons license, and indicate if changes were made.

Electronic supplementary material The online version of this article (doi:10.1007/s00232-015-9849-y) contains supplementary material, which is available to authorized users.

\section{J. Fischbarg}

jf20@ columbia.edu

1 ININCA, Conicet, Marcelo T. de Alvear 2270,

CP 1122AAJ Buenos Aires, Argentina 